\title{
Investigating Primary School Teachers' Perception About Democracy Through Metaphor Analysis
}

\author{
Hasan Nasirci ${ }^{*}$ \\ Kazim Karabekir Special Education Centre, TURKEY
}

\author{
Fatma Sadik \\ Cukurova University, TURKEY
}

Received: November 3, 2017 - Revised: November 15, $2017 \cdot$ Accepted: December 21, 2017

\begin{abstract}
The aim of this study is to examine democracy perception of classroom teachers via metaphor analysis. Study group for research is formed of 253 classroom teachers. "Democracy Metaphors Questionnaire" (DMQ) has been used in collecting data. Content analysis has been used on analysis of qualitative data of research and descriptive statistics have been used on quantitative data. The metaphors that teachers developed with a total 122 metaphor different from one another about democracy are gathered under "Indispensability", "Equality", "Social Order", "Freedom", "Endeavour", "Power", "Variety", "Progression", "Conservation", "Personal Gains" and "Nothingness". While first three themes under which women teachers gathered being indispensability, equality and endeavour metaphors, men teachers are gathered under indispensability, social order and freedom metaphors. Family environment and upbringing, relations with friends, culture of social environment, political activities in society and news in media tools have been the effective factors in forming democracy perception that the teachers possess.
\end{abstract}

Keywords: Democracy, democracy perception, metaphor, primary school teacher.

To cite this article: Nasirci, H., \& Sadik, F. (2018). Investigating primary school teachers' perception about democracy through metaphor analysis. European Journal of Educational Research, 7(1), 121-132. doi: 10.12973/eu-jer.7.1.121

\section{Introduction}

Democracy is not only a political concept, it is a social condition involving specific values as well as principles, affecting the people's life in general, and it is a life style at the same time (Buyukkaragoz, 1990; Dewey, 1996). Adopting democracy as a life style by the society depends on an effective education about democracy (Apple \& Bean, 2011; Goodlad, 1997). Democracy education starts within the family. Additionally, the establishment of democratic values and behavior comes true within the entire social process. All social domains of the individual including educational institutions, friends, and mass communications are involved in this process (Doganay, 2009). However, schools play an important role in adopting democratic values, attitude and behavior besides developing the students' specific skills (Dewey, 1996; Subba, 2014). Therefore, it is expected that educational institutions in democratic societies educate democratic individuals, show efforts to form good citizens and a good society (Branson, 2004). In this regard, teachers are the first person with the capacity to have an impact on the children as the practitioners of the curriculum and the democracy education in school settings.

According to Burden (1995) and Doyle (1986), the role of teachers is to help the students to become self-respecting, self-confident, as well as psychologically and socially competent besides enabling the students to learn specific information. In this process, teachers being a positive role model with their behavior and attitude in the classrooms is very important to develop students and young adults to democratic citizens. In this case, it can be said that teachers do formal democracy education with the methods and techniques used in the classroom settings. It can be said that they also do hidden democracy education thanks to their relationships with the students, their reactions and behaviors about the cases in classrooms (Yuksel, 2004). Doganay (2009) believes that a hidden program is much more effective than a written program for the acquisition of these values. Therefore, all the staff at schools, especially teachers, should act consciously and schools should become an area where democratic values are experienced within this small unit of society. The related research has proved this view by revealing that a hidden conveying makes significant contributions to develop democratic behaviors such as group life, fulfilling responsibilities, and self-control (Anyon, 1983; Doganay \& Sari, 2004; Kirk, 1992; Sari, 2007; Tuncel, 2008).

\footnotetext{
* Corresponding author:

Hasan Nasirci, Kazim Karabekir Special Education Centre, Turkey.

Email: hasannasirci@gmail.com
} 
The teachers' characteristics are important factors in actualizing a democratic education (Karatekin, Merey \& Kus, 2013). According to Kucukahmet (2009), the most important personal trait of a teacher, impacting the students' learning and social development, is their attitude towards their students and school practices. The core of this attitude is the manner developed in the individual towards the situation. Attitude consists of the three components "conscious" based on learning, "affective" referring to emotions, and "behavioral" through which reactions are caused (Ozcelik, 1995). The "Conscious" element is our belief, preference or perception about an observable object. It can be confirmed either as a result of direct interaction or by means of information through mass communication, education and other people etc. (Pehlivan, 1997). The "affective" element that brings continuity and shapes the attitude is formed by emotions such as fear, anger, worry, love etc. based on beliefs (Erdogan, 1999). The "affective" aspect closely relates to systems of values of people and is a predisposition towards positive or negative reactions. A person's positive or negative feelings are based on his/her past experience (Inceoglu, 1993). If people have a positive attitude towards a person, an object, a case, a situation, a concept etc., they will behave accordingly. In this case, teachers should, first of all, sufficiently adopt a democratic attitude and ideals in their inner world to infuse a democratic understanding and ideals into their students (Hokelekli \& Gunduz, 2007; Shechtman, 2002; Yalcin, 2014). Because teachers never teach the information of the official syllabus or course books identically during their classes. They reflect their own views, thoughts, beliefs and understanding about the subject either hidden or obviously (Kocoska, 2009; Yuksel, 2004). Therefore, it can be said that forming attitudes, values and behaviors proposed in the syllabi are usually based on the teachers rather than the information in the content of the program.

Nowadays, the level of democratic society which is expected to be reached is directly proportional to the level of educating democratic teachers (Hartnett \& Michael Naish, 1993). Therefore, the democratic attitude and behavior of teachers as well as pre-service teachers in different disciplines have often been the issue of research studies (Dworkin, Saha \& Hill, 2003; Kaya, 2013; Kesici, Pesen \& Oral, 2017; Kurnaz, 2011; Peker, 2012; Richardson, 1996; Ustun, 2011; Yalcin, 2014). However, it is much more important that primary school teachers have democratic features because students formally meet concepts related to democracy such as equality, rights, freedom, human honor, tolerance, and respect for diversity first during primary school (Samanci, 2010). Besides that, little children pay more attention to the actions of their teachers rather than to what they tell and they are more open to be affected by the behavior of their teachers (Kucukahmet, 2009). Attitudes usually root in the childhood and the effects of experiences during childhood last all lifelong (Kagitcibasi, 2005). Therefore, the related literature focuses on primary schools and the investigation of primary school teachers' democratic attitude and behavior with regard to different variables (such as the years of experience, classroom management behavior, thinking skills, attitudes towards children rights, etc.) (Kaya, 2013; Kurnaz, 2011; Payne, 2017; Peker, 2012; Rainer \& Guyton, 1999; Sadik \& Sari, 2011; Ustun, 2011). However, it has been detected that research has mostly been done by quantitative methods and qualitative studies are very limited considering the research studies. A study investigating the perceptions of primary school teachers about democracy could not been found.

Due to the fact that perceptions dominate attitudes and that the teachers' attitudes towards democracy might depend on their perception about democracy, the researchers were in need of a study investigating the primary school teachers' perception about democracy through metaphor analysis and they wanted to find answers for the following questions:

1. What are the metaphors developed by primary school teachers about democracy and what are their explanations about the reasons to use these metaphors?

2. Are the metaphors developed by primary school teachers about democracy showing differences based on their gender?

3. What are the factors affecting the perception of democracy of primary school teachers?

\section{Research Goal}

\section{Methodology}

This is a qualitative phenomenology designed research study. The purpose of this phenomenology research is to reveal the experiences and perceptions of individuals about a concept and the meanings they have assigned to this (Creswell, 2007). The matter of fact in this study is democracy, related to all aspects of life, and whose principles, values, and practices are discussed very often. In this study, the primary school teachers' perception about the concept of democracy was investigated by means of metaphors. According to Lakoff and Johnson (2005), metaphors about language and the way language is used is a way for human beings to understand the nature and the environment, to make sense of an objective reality which seems meaningless through specific interpretations as well as to add value to their life and experiences. The reason for doing the research with primary school teachers is the importance of democracy education at an early age and that primary schools underlie the main education level in this regard. 


\section{Sample and Data Collection}

For the phenomenologic method, it is important to choose the participants who will explain the phenomenon carefully and to work with the first persons who will be able to reflect about the phenomenon (Patton, 2002; Creswell, 2007). Therefore, this research study was conducted with the first persons in charge of a democratic education at schools, the teachers. The reason of working with primary school teachers is the importance of starting a democratic education at an early age and primary school are the main education level in this respect. The study group consists of 253 primary school teachers in total, 160 female and 93 male, working at primary schools in the central districts of Adana during the academic year 2014-2015. The probability-based cluster sampling method was used to form the working group. The "Democracy Metaphors Questionnaire" (DMQ) developed by Sari and Sadik (2011) was used to collect the data of the study through adopting the features of the working group. The first part of the DMQ consists of questions related to demographic information about the participating teachers. In the second part, the participating teachers were asked to fill in the gaps in a sentence stating "I think democracy is like .............." Because ".................." by developing metaphors and giving explanations to detect the primary school teachers' perception about democracy. The last question is about the factors affecting the teachers' perceptions about democracy. In this respect, 17 factors were determined in the literature review and designed in a 5-Likert scale (5 means certainly effective and 1 means does not affect at all). The data was collected during school visits in the second semester of the academic year 2014-2015. For the data collection, first the required permission was received and then the school administrations were informed about the research study. No problems occurred during the in average 20-min-long execution. The researcher was at the school setting while conducting the research in the teachers' room during the break-times and the lunch breaks.

\section{Analyzing of Data}

A content analysis was used for the qualitative data of the study while descriptive statistics were used for the quantitative data through SPSS 21 (frequency \% and arithmetic mean). 253 questionnaires were initially evaluated in terms of clearness to read for the qualitative data analysis and it was detected that there was no problem. Then the questionnaire was transferred into a Word document and the coding phase based on the individual data gained from the participants started. In this phase, the written sentences were read line by line by the researchers, important aspects were detected based on the purpose of the study, and some specific codes were created according to the meaning. The coded parts were highlighted and the codes were noted according to their margins and the researcher performed a "re-reading" and "referring to the literature" during the process. As for the reliability of the codes, the results were compared to avoid prejudice and misunderstandings in the coding. The reliability of the coding was evaluated through the formula of Miles and Huberman (1994), which is reliability=agreement/agreement + disagreement $\times 100$, and the agreement rate between two coders was evaluated as .94 . In the second phase of the content analysis, the codes were combined and categorized according to their relation and common parts (Yildirim \& Simsek, 2011). In this phase of the analysis, the researcher and the advisor worked together and themes were formed based on related literature as well as the research questions and the metaphors developed about democracy. The participating teachers were given numbers from 1 to 253 while transferring the views of the teachers and an initial of their gender was written next to the number. For instance, $1 \mathrm{M}$ means this is the view from the number 1 teacher and this teacher is a male teacher; $22 \mathrm{~F}$ means the answer is from the teacher number 22, who is a female.

\section{Results}

\section{Findings related to the metaphors developed by primary school teachers about democracy}

As a result of the analysis, it was found that three primary school teachers out of the 253 participants did not state a specific metaphor but explained the meaning of democracy while 250 participants developed 122 separate metaphors. These metaphors were sorted under 11 themes based on common features while some metaphors were also placed under various themes because of the various explanations given by the participants. The frequency and percentage values of the themes are given in Table 1. 
Table1. The metaphors developed by the primary school teachers according to the themes

\begin{tabular}{|c|c|c|c|}
\hline Theme & Metaphors & $\mathrm{f}$ & $\%$ \\
\hline Indispensability & $\begin{array}{l}\text { Water (f:16), Air (f:11), Sun (f:8), Bread (f:5), Breath (f:3), } \\
\text { Life (f:3), Oxygen (f:3), Medication (f:2), Health (f:1), Home } \\
(f: 1) \text {, Mother (f:1), Soil (f:1), Food (f:1), Energy (f:1), Eyes } \\
(f: 1)\end{array}$ & 59 & 23.6 \\
\hline Equality & $\begin{array}{l}\text { Scale (f:18), Water (f:2), Daisy (f:1), Mother (f:1), Spring } \\
\text { water (f:1), Mirror (f:1), Natural life (f:1), the Sun (f:1), } \\
\text { Herd (f:1), Agreement (f:1), Birds' migration (f:1), Zam-zam } \\
\text { water (f:1), Referee (f:1) }\end{array}$ & 31 & 12.4 \\
\hline Social order & $\begin{array}{l}\text { Family (f:3), Mirror (f:3), Life Style (f:2), Life (f:2), Hive } \\
\text { (f:2), Sword (f:2), Ataturkist ideology (f:1), Common } \\
\text { ground (f:1), Host (f:1), Conversation (f:1), Gearwheel (f:1), } \\
\text { Paper (f:1), Scale (f:1), World (f:1), Key (f:1), Soil (f:1), } \\
\text { Maths (f:1), Pen (f:1) }\end{array}$ & 26 & 10.4 \\
\hline Effort & $\begin{array}{l}\text { Flower (f:7), Child (f:2), Tree (f:2), Ruby (f:1), Self- } \\
\text { confidence (f:1), Orchid (f:1), Young tree (f:1), } \\
\text { Conservation (f:1), Snowdrop (f:1), Juicy peach (f:1), Love } \\
(f: 1) \text {, Happiness (f:1), Arrow (f:1), Tight (f:1), Aspirin (f:1), } \\
\text { Salt (f:1) }\end{array}$ & 24 & 9.6 \\
\hline Freedom & $\begin{array}{l}\text { Bird (f:6), Butterfly (f:2), Ocean (f:2), Kid (f:2), Fish (f:2), } \\
\text { Pigeon (f:1), Flower (f:2), Star (f:1), Tree (f:1), Survivor } \\
(f: 1) \text {, Cotton (f:1), Wild flowers (f:1), Sun (f:1), Horse (f:1) }\end{array}$ & 24 & 9.6 \\
\hline Personal gains & $\begin{array}{l}\text { Tire (f:4), Bitten Apple (f:1), Toy (f:1), Phases of moon (f:1), } \\
\text { Handkerchief (f:1), Fork (f:1), Water (f:1), Arbitrary power } \\
\text { (f:1), Flying Balloon (f:1), Chameleon (f:1), Scale (f:1), } \\
\text { Scratch pad (f:1), Description of an elephant by a blind } \\
\text { person (f:1), Horse (f:1), Ball (f:1), Cloud (f:1), Weapon (f:1) }\end{array}$ & 20 & 8.0 \\
\hline Power & $\begin{array}{l}\text { Tree (f:4), Eagle (f:2), Stick (f:1), Flame (f:1), Knife (f:1), } \\
\text { Plane tree (f:1), Magical stick (f:1), Castle (f:1), Child (f:1), } \\
\text { Soap (f:1), Chain (f:1), Rain (f:1), Pillar (f:1), Sun (f:1) }\end{array}$ & 18 & 7.2 \\
\hline Diversity & $\begin{array}{l}\text { Rainbow (f:3), Flower garden (f:2), Starfish (f:1), Tree (f:1), } \\
\text { Forest (f:1), Nature (f:1), Cake (f:1), Elevator (f:1), Pan (f:1), } \\
\text { Color wheel (f:1), Pineapple (f:1) }\end{array}$ & 14 & 5.6 \\
\hline Progress & $\begin{array}{l}\text { Teacher (f:2), Book (f:2), Star (f:1), Moon (f:1), Light (f:1), } \\
\text { Sun (f:1), Rich soil (f:1), Turkey (f:1), Projector (f:1), Wind } \\
(f: 1) \text {, Ladder (f:1) }\end{array}$ & 13 & 5.2 \\
\hline Protectiveness & $\begin{array}{l}\text { Mother (f:6), Umbrella (f:2), Parents (f:2), Close friend (f:1), } \\
\text { Tree (f:1), Home (f:1) }\end{array}$ & 13 & 5.2 \\
\hline Nothingness & $\begin{array}{l}\text { Carrying water in a sieve (f:1), Dream (f:1), Advertising } \\
\text { (f:1), Faded flower (f:1), Opposite of real meaning (f:1), } \\
\text { Darkness (f:1), Pie in the sky (f:1), Utopia (f:1) }\end{array}$ & 8 & 3.2 \\
\hline Total & & 250 & 100 \\
\hline
\end{tabular}

As can be seen in Table 1, the metaphors developed by the primary school teachers focused mainly around the theme "indispensability" (f:59). This theme is followed by "equality" (f:31), "social order" (f:26), "effort" (f:24), "freedom" (f:24), "personal gains" (f:20), "power" (f:18), "diversity" (f:14), "progress" (f:13), "protectiveness" (f:13), and "nothingness" ( $\mathrm{f}: 13$ ) respectively. The metaphors and the explanations are explained under the themes in the following:

\section{Theme 1: Indispensability}

In this theme, metaphors about water (f:16) and air (f:11) were very prominent and the reason as something we need was given. For example, while a male teacher expresses the metaphor air saying "When there is no democracy, life is getting difficult. Like asthma patients, oxygen is needed", a female teacher explained it as "Democracy is indispensable like water. Without democracy, human life cannot be qualitative and happy". The participating teachers used similar explanations like "it gets difficult, we drown, we cannot live without etc." to show the vital importance. Other metaphors in this theme were the sun (f:8), bread (f:5), breath (f:3), life (f:3), oxygen (f:3), medication (f:2), health, home, mother, soil, food, energy, and eyes. For instance: 
"If there is no democracy, then there is no humanity, there is no nature for life, there is nothing to feed humanity" (106M)

"It got difficult and we got snowedbound like getting stuck in a trap or a lack of air in the places where there is no democracy" (132F).

\section{Theme 2: Equality}

The most obvious metaphor in this theme, "scale" (f:18) is originated with equality and justice. Similarly, equal distribution, equal treatment, etc. explanations were emphasized for the metaphors of water (f:2), daisy (f:1), mother, spring water, mirror, natural life, the sun, herd, agreement, birds migration, zam-zam water, and referee. Some samples are following:

"Democracy is like a referee because the rights of the people are protected with objectivity, equal treatment and possessing equal rights" (38F)

"When there is no democracy or when it is destroyed, the balance of the scale collapses.

Democracy should be balanced like a pair of scales" (152F)

\section{Theme 3: Social Order}

Democracy was perceived as a system with specific rules, which requires cooperation and agreement, orders the social life, solves problems and also develops by going through specific phases in the metaphors developed in this theme [family (f:3), mirror (f:3), life style (f:2), life (f:2), hive (f:2), sword (f:2), Ataturkist ideology, common ground, host, conversation, gearwheel, paper, scale, world, key, soil, math, pen]. The following statements are samples from the participant teachers about the metaphors:
"Democracy is like a host taking care of the guests because the goal is to keep various groups with different ideas and wishes together and satisfy them at the same time" (136F)
"Gearwheel moves when it turns because this is the system. When it stops, democracy does not work" (206F)
"If family members do what they should do, then the family can live. All individuals should do what they supposed to do to keep democracy alive (87M).

\section{Theme 4: Effort}

The most common metaphors in this theme were flower (f:7), child (f:2), tree(f:2) and were explained as "the better one takes care and supports the growing, the better result are gained". For the other metaphors developed by the participants (ruby, self-confidence, orchid, young tree, snowflake, juicy peach, love, salt, ok, tight, happiness, aspirin), democracy was explained as a value requiring efforts to develop and special care to be protected. In the following, some explanations of the participants are given:

"Democracy is like a flower because when you take care of it well then it can develop, grow, and the world will be covered with a nice smell" (94M)

"Democracy is a fact needed to be transferred from one generation to the other. When you treat a child in a nice way, the child treats you back nicely. Similarly, the better use you make of democracy, the longer it sustains" (194M)

\section{Theme 5: Freedom}

The most common metaphor in the freedom theme, "bird" (f:6) was justified as "freely flying in the sky and having its own habitat where it can move independently". Democracy was explained as a system expressing thoughts and emotions, the freedom of movement and saving others from captivity with the other metaphors [butterfly (f:2), ocean (f:2), kid (f:2), fish (f:2), pigeon (f:1), wild flower, star, tree, survivor, cotton, the sun, horse]. Sample explanations by the participating teachers are given below:

"Democracy is like wild flowers as it chooses its own color, it blooms and then dies. However, it also leaves whatever it wants behind" (86M).

"Butterflies fly independently. We also feel free and independent with democracy" (85M)

\section{Theme 6: Personal gains}

Negative metaphors were given in this theme and the explanations centered on the problems with the performance and interpretation of democracy. The teachers perceived democracy as a regime which is shaped according to personal 
gains and is used by powerful people based on their own goals. For example, "rubber" (f:4) was associated with the idea "it moves whenever you stretch". Here are some example explanations of the participants:

"When democracy is performed and approached holistically, it is nice. An apple consumed by bites is nice but for the biter parts" (3F)

"Today democracy is like a ball because it moves wherever it is kicked" (203M)

"Democracy is like a toy, it works in accordance with the goals and objectives of those who have the authority" (4F)

\section{Theme 7: Power}

The metaphors in the theme power (f:18) refer to the constructive and remedial power of democracy, its feature of retaining the power and its durability. The participating teachers explained that democracy holds the soil tight with its roots and raises to the sky in the metaphor "tree", which has the highest frequency (f:4). Some other explanations for further metaphors are:

"Democracy keeps societies alive like the columns holding a building"(117M)

"Democracy is like a castle. The stronger walls the castle has, the more difficult it is to collapse" (189F)

"It is like a knife, having the power to either create magnificently shaped artwork or to harm a person whenever one wants" (35F).

\section{Theme 8: Diversity}

The metaphors in this theme usually focused on the democracy feature of sheltering diversity and polyphony in harmony. The "rainbow" (f:3) was the most common metaphor, followed by flower garden (f:2), color wheel, forest, tree, cake, nature, elevator, pan, starfish, and pineapple respectively. Some sample explanations of the participants are given below:

"Democracy is like a rainbow because it contains different ideas and cultures" (65F)

"Democracy is like a forest, there are various trees and animals in a forest. They are free and their life and relation with each other usually takes place naturally" (70F)

"Democracy is as nice as a cake; it contains a lot of things mixed inside. It is the harmony of different flavors" (150F)

\section{Theme 9: Progress}

Among the metaphors developed in the progress theme, "teacher" (f:2) and "book" (f:2) were reported to be developed because of the leading and directing features of democracy. Similarly, democracy was explained as a structure providing growth, development and moving forwards through the metaphors star, moon, sun, rich soil, Turkey, light, projector, wind and ladder. For example:

"Democracy is like a book; it brightens people and makes them independent" (112M)

"Democracy is like a projector, it discourages darkness, brings peace and good moral" (19F)

"Democracy is like a teacher because teachers guide in the educational life, make students active, and enable them to participate. They are organizers. They provide creativity. They provide guidance. As a result, students become active. They can defend and manage themselves" (245F).

\section{Theme 10: Protectiveness}

The metaphors in this theme (mother (f:6), umbrella (f:2), parents (f:2), close friend, tree, home) emphasize the protecting and sustaining human rights feature of democracy. For example:

"Democracy is like a tree. A tree shelters many living creators. It provides trust with its strong branches and tree-trunk. It is protective, comprehensive and accessible for all living creators with its benefits such as oxygen and shade". (159F)

"Democracy feeds, raises grows, and protects children like a mother. It aims to raise wellbehaved humans". (139M)

"It protects from the sun and the rain like an umbrella. Democracy also demonstrates that we need to protect our rights, to look for our rights and that the others also have rights" (27F). 


\section{Theme 11: Nothingness}

The participating teachers explained their negative feelings towards the problems and bad experiences about fixing and adopting democracy as a life style of the society (hopelessness, worry and fear). For example:

"I do not believe that there is democracy in any area in our country. It is only a dream which is fading away". (37F)

"Just like in the darkness, we cannot see in which direction our country is moving. We cannot freely share our selves and our ideas. We are worried about the future of our children". (179F)

2. The metaphors developed by primary school teachers about democracy according to their gender

The distribution of metaphors developed by the participants according to their gender is given in Table 2 .

Table2. The metaphors according to the gender of the participants

\begin{tabular}{|c|c|c|c|c|}
\hline Theme & $\begin{array}{l}\text { Female } \\
\mathrm{N}: 153\end{array}$ & $\begin{array}{l}\text { Male } \\
\mathrm{N}: 97 \\
\end{array}$ & $\mathrm{f}$ & $\%$ \\
\hline Indispensability & $\begin{array}{l}\text { Metaphor: } 11 \\
\text { f: } 36 \\
\% 61.0\end{array}$ & $\begin{array}{l}\text { Metaphor: } 10 \\
\text { f: } 23 \\
\% 39.0\end{array}$ & 59 & 23.6 \\
\hline Equality & $\begin{array}{l}\text { Metaphor: } 5 \\
\text { f: } 19 \\
\% 61.3\end{array}$ & $\begin{array}{l}\text { Metaphor: } 9 \\
\text { f: } 12 \\
\% 38.7\end{array}$ & 31 & 12.4 \\
\hline Social order & $\begin{array}{l}\text { Metaphor: } 10 \\
\text { f: } 10 \\
\% 38.5\end{array}$ & $\begin{array}{l}\text { Metaphor: } 12 \\
\text { f: } 16 \\
\% 61.5\end{array}$ & 26 & 10.4 \\
\hline Effort & $\begin{array}{l}\text { Metaphor: } 14 \\
\text { f: } 17 \\
\% 70.8\end{array}$ & $\begin{array}{l}\text { Metaphor: } 4 \\
\text { f:7 } \\
\% 29.1\end{array}$ & 24 & 9.6 \\
\hline Freedom & $\begin{array}{l}\text { Metaphor: } 9 \\
\text { f: } 13 \\
\% 54.2\end{array}$ & $\begin{array}{l}\text { Metaphor: } 8 \\
\text { f: } 11 \\
\% 45.8\end{array}$ & 24 & 9.6 \\
\hline Personal gains & $\begin{array}{l}\text { Metaphor: } 9 \\
\text { f: } 10 \\
\% 50.0\end{array}$ & $\begin{array}{l}\text { Metaphor: } 9 \\
\text { f: } 10 \\
\% 50.0\end{array}$ & 20 & 8.0 \\
\hline Power & $\begin{array}{l}\text { Metaphor: } 11 \\
\text { f: } 14 \\
\% 77.8\end{array}$ & $\begin{array}{l}\text { Metaphor: } 3 \\
\text { f: } 4 \\
\% 22.2\end{array}$ & 18 & 7.2 \\
\hline Diversity & $\begin{array}{l}\text { Metaphor: } 9 \\
\text { f: } 11 \\
\% 78.5\end{array}$ & $\begin{array}{l}\text { Metaphor: } 3 \\
\text { f: } 3 \\
\% 21.5\end{array}$ & 14 & 5.6 \\
\hline Progress & $\begin{array}{l}\text { Metaphor: } 8 \\
\text { f: } 9 \\
\% 69.2\end{array}$ & $\begin{array}{l}\text { Metaphor: } 4 \\
\text { f: } 4 \\
\% 30.8\end{array}$ & 13 & 5.2 \\
\hline Protectiveness & $\begin{array}{l}\text { Metaphor: } 6 \\
\text { f: } 8 \\
\% 61.5\end{array}$ & $\begin{array}{l}\text { Metaphor: } 3 \\
\text { f: } 5 \\
\% 38.5\end{array}$ & 13 & 5.2 \\
\hline Nothingness & $\begin{array}{l}\text { Metaphor: } 6 \\
\text { f: } 6 \\
\% 75.0\end{array}$ & $\begin{array}{l}\text { Metaphor: } 2 \\
\text { f: } 2 \\
\% 25.0\end{array}$ & 8 & 3.2 \\
\hline
\end{tabular}


As can be seen in Table 2, the metaphors developed by female teachers could mainly be grouped under the themes "Indispensability" (f:36), "Equality" (f:19), "Effort" (f:17), "Power" (f:14), and "Freedom" (f:13). These are followed by "Diversity" (f:11), "Social Order" and "Personal gains" (f:10), "Progress" (f:9), "Protectiveness" (f:8), and "Nothingness" (f:6) respectively. When considering Table 2 with regard to the male teachers' expressions, it can be seen that they mostly developed metaphors emphasizing the indispensability (f:23) and necessity in terms of social order (f:16), which is similar to those by the female participants. These metaphors are followed by "Equality" (f:12) and "Personal Gains" (f:10), "Effort" (f:7), "Protectiveness" (f:5), "Power" and "Progress" (f:4), "Diversity" (f:3) and "Nothingness" (f:2) respectively based on the percentages.

\section{The findings concerning the factors affecting the perception of the teachers about democracy}

The descriptive statistics about the primary school teachers' views related to the factors affecting their perception of democracy are given in Table 3 .

Table3. The factors affecting the perception of the teachers about democracy

\begin{tabular}{lcc}
\hline Factors & Mean & $\begin{array}{c}\text { Standard } \\
\text { dev. }\end{array}$ \\
\hline Family and upbringing & 4.38 & .94 \\
Relationships with friends & 4.10 & .99 \\
The culture of the social environment & 4.03 & 1.09 \\
Political activities in the society & 3.84 & 1.26 \\
The news in the media (newspapers, television, the internet etc.) & 3.82 & 1.26 \\
Books read in free time & 3.81 & 1.10 \\
The behavior and attitude of their lecturers during their education & 3.79 & 1.23 \\
Academic activities (congress, conference, symposium, panel, etc.) & 3.63 & 1.14 \\
Courses taken during their education (primary and secondary education, & 3.59 & 1.13 \\
college) & 3.56 & 1.31 \\
Course materials (methods, techniques, activities, etc.) & 3.43 & 1.42 \\
The behavior and attitudes of the principles at their schools & 3.43 & 1.14 \\
Social, cultural, artistic and sportive activities & 3.41 & 1.41 \\
The behavior and attitude of the colleagues at their schools & 3.36 & 1.39 \\
Trade-union activities & 3.33 & 1.30 \\
Course-books & 3.14 & 1.35 \\
Television series and movies & 2.81 & 1.31 \\
\hline
\end{tabular}

As can be seen in Table 3, the primary school teachers' perception about democracy were mostly affected by family and their upbringing environment, the relationships with friends, the culture of the social environment, political activities in the society, and the news in the media. Based on the findings, flyers, brochures, photographs, graffiti around, television series and movies, course books and trade-union activities were found to affect the participant's perception about democracy less than the other factors.

\section{Discussion and Conclusion}

At the end of the research study, it was detected that most of the metaphors developed by the participants were grouped under the theme "indispensability" and democracy was defined as essential for the social life. Other themes under which many of the metaphors were grouped were equality, social order, effort, and freedom respectively, based on their percentage rates. Democracy means a regime in which fundamental rights and liberties are secured (Kongar, 2007). Therefore, equality and freedom, fundamental rights and liberties, are the main features associated with democracy and democratic values (Kincal \& Isik, 2003). Similar results were also found in the research studies on primary school teachers by Sadik and Sari (2011) and pre-service teachers by Sari and Sadik (2011), these studies revealed that pre-service teachers described democracy with concepts such as equality, freedom and independency. The fact that the teachers mostly emphasized indispensability with the metaphors they developed might originate from their worries about a disappearing of democratic values. In fact, their statements about the necessity of protecting democracy with great efforts, which was described as indispensable for the social order and a peaceful life, support this idea. Moreover, the low number of teachers who think that democracy must be protected and developed by huge efforts might reveal that the participants do not have a strong belief in making contributions to the democratization process. Similar results found in the study on pre-service teachers by Gursimsek and Goregenli (2004) also support this view. 
At the end of the study it was seen that the power, diversity, progress and protectiveness themes were placed in the lower part of the list according to their percentage rates when compared to others; some teachers even developed negative metaphors about "personal gains" and "nothingness". The only reference for democracy is the society. In antidemocratic regimes, dominance belongs to one person or one group. Interest for and participation of fellow citizens in the government is only possible with tolerance, respect for different ideas and by adopting equalitarian relationships. Therefore, the fact that teachers emphasized these ideas less than others with their metaphors might be an indicator that they either disregard the fact that there could be different ideas in the society or they think that there is no progress in creating and protecting diversity in the society. However, the idea was also supported that teachers think that democracy is shaped in accordance with personal gains under the theme "personal gains" and that they consider democracy as an impossible regime and a hollow application in the "nothingness" theme and, to summarize it, teachers have a critical approach towards democracy.

The results of the study show that the metaphors developed by female teachers were usually grouped within the first three themes "indispensability", "equality" and "effort" while the metaphors of the male teachers were under "indispensability" and "freedom". The superiority of the "indispensability" theme could be considered as an indicator that teachers give importance to democracy and believe that democracy is a good regime. The reasons for female teachers using the metaphor "scale" to emphasize the equality principle following the indispensability feature of democracy might be fact that there is inequality in the roles and responsibilities of women and men in the sociocultural life and that female teachers think they are not treated equally.

According to the results of the study, the participants' perception about democracy was mostly affected by their family life and their upbringing style. This is followed by relationships with friends, the culture of the social environment, political activities in the society, and news in the media. This result is similar to related literature showing that young people's learning of politics and democracy as well as perceptions of being a good citizen (Print, 2007) and democracy is affected by their families (Sari \& Sadik, 2011). According to Bandura's social learning theory, human beings learn many behaviors from others around through observing (Erden \& Akman, 1995). Therefore, since the first people who individuals observe and take as role model are usually family members, it is not possible to isolate the family life from the perception of democracy. Many studies reveal that the audio and visual press, in other words the media, has a permanent impact not only on children but also on adults in any subject nowadays (Albayrak, Albayrak, Kucukyilmaz \& Guven, 2011; Arslan, 2006; Kara, 2011). The goal of the mass media is to provide the society with correct and objective information about political, economic, scientific, literature, and cultural events, to make explanations about the government, and to reveal abuses in society. In short, the task of the media is supervision, criticizing, warning and explaining reality. Freedom is required to do its duty (Coronel, 2001; Celebi, 1997). Therefore, this result shows that the media has the power to provide direct and indirect democratic education through both the news considering the freedom of communication and personal rights and the authenticity of the news. Flyers, brochures, photographs and graffiti around are the least effective factors for the teachers' perceptions about democracy because these visual stimuli are not enough and not used regularly or they are not satisfactory to raise awareness about democracy alone.

In accordance to the findings of the study, the teachers' as well as the pre-service teachers' professional experience and skills could be enhanced by taking precautions about a democratic education in both the pre-service teacher's training programs and the in-service training programs and by increasing the number of hands-on activities. Teachers can create groups within their workplaces at schools and design projects to materialize democratic principles (excursions, debates, school newsletter, social clubs, etc.). It can be suggested that to raise awareness and sensibility of students and parents, teachers should organize social projects, curriculum development projects, and activities to encourage an participative environment for decisions about the school, encourage opportunities where the basic principles of democracy can be experienced through organizing panels, colloquiums, seminars, forums, workshops, etc. to create discussion possibilities about subjects such as democracy, democracy at home, and democratic parents, make use of posters, photos and cartoons about metaphors emphasizing the fundamental principles of democracy in the corridors, school yards, walls and classroom boards.

\section{Acknowledgements}

This study was supported by Cukurova University Scientific Research Projects (project number: SYL-2015-3829).

\section{References}

Albayrak, E., Albayrak, S., Kucukyilmaz, M. M., \& Guven, S. (2011). Toplumun, kultur politikalari ve medyanin kulturel sureclere etki algisi arastirmasi [A study about cultural politics of society and the influence of media on cultural processes]. Retrieved from http://www.sinema.gov.tr/ 
Anyon, J. (1983). Intersections of gender and class: Accommodation and resistance by working class and affluent females to contradictory sex-role ideologies. In S. Walker \& L. Barton (Eds.), Gender class \& education (p. 19-38). USA: The Falmer.

Apple, M. W., \& Beane, J. A. (2011). Demokratik okullar [Democratic schools]. (Translation. M. Sari). Ankara: Dipnot Yayinlari.

Arslan, A. (2006). Medyanin birey, toplum ve kultur uzerine etkileri [The influence of media on individuals, culture and society]. International Journal of Human Sciences, 1(1) 1-12.

Branson, M. S. (2004). Education for citizenship and the teaching of democracy in schools. International Symposium on Democracy Education, Canakkale, Turkiye, 2004.

Burden, P. R. (1995). Classroom management and discipline. NY: Longman.

Buyukkaragoz, S. (1990). Demokrasi egitimi [Democracy education]. Ankara: Turk Demokrasi Vakfi.

Coronel, S. (2001). The role of media in deepening democracy. Retrieved from http://unpan1.un.org/intradoc/groups/public/documents/un/unpan010194.pdf

Creswell, J. W. (2007). Qualitative inquiry \& research design: Choosing among five traditions. California: Sage.

Celebi, F. (1997). Kisilik haklarindan kisinin ozel yasami ve gizliliklerinin ihlali ve korunmasi [Violation and protection of personal life and privacy of the person]. Kocaeli Universitesi Hukuk Fakultesi Dergisi, 1, 271-296.

Dewey, J. (1996). Demokrasi ve egitim [Democracy and education]. (Translation. Y. Yilmaz). Izmir: Ege Universitesi Basimevi.

Doganay, A., \& Sari, M. (2004). Ilkogretim ikinci kademe ogrencilerine temel demokratik degerlerin kazandirilma duzeyi ve bu degerlerin kazandirilmasi surecinde acik ve ortuk programin etkilerinin karsilastirilmasi [Elementary school students' devotion level to democratic values and comparison of the effect of overt and hidden curriculum -on gaining democratic values in terms of students and teachers opinions]. Egitim Yonetimi, 10(39) 356 $-383$.

Doganay, A. (2009). Degerler egitimi [Values education]. In C. Ozturk (Ed.), Sosyal bilgiler ogretimi [Teaching social studies] (p. 223-256), Ankara: PegemA Yayincilik.

Doyle, W. (1986). Classroom organization and management. M. C. Wittrock (Ed.), Handbook of research on teaching (p.392-431). New York: Mc. Millan.

Dworkin, A. G., Saha, L. J., \& Hill, A. N. (2003). Teacher burnout and perceptions of a democratic school environment. International Educational Journal, 4 (2), 108-120.

Erden, M., \& Akman, Y. (1995). Egitim psikolojisi, gelisim-ogrenme-ogretme [Educational psychology, developmentlearning-teaching]. Ankara: Arkadas Yayinevi.

Erdogan, I. (1999). Isletmelerde davranis [Behavior in businesses]. Istanbul: Evrim Yayinevi.

Goodlad, J. I. (1997). In praise of education. New York: Teachers College Press.

Gursimsek, I., \& Goregenli, M. (2004). Ogretmen adaylari ve ogretmenlerde demokratik tutumlar, degerler ve demokrasiye iliskin inanclar [Democratic attitudes, values and beliefs about democracy in teacher candidates and teachers]. Uluslararasi Demokrasi Egitimi Sempozyumu Bildiriler Kitabi, 77-85.

Hartnett, A., \& Naish, M. (1993). Democracy, teachers and the struggle for education: An essay in the political economy of teacher education. Curriculum Studies1 (3), 335-348, Doi Number: 10.1080/0965975930010303

Hokelekli, H., \& Gunduz, T. (2004). Ustun yetenekli cocuklarin deger yonelimleri [Value orientation of gifted children]. Degerler ve Egitimi Uluslararasi Sempozyumu, Istanbul: Degerler Egitimi Merkezi, 26-28 November 2004.

Inceoglu, M. (1993). Tutum, algi, iletisim [Attitude, perception, communication]. Ankara: V Yayinlari. 
Kagitcibasi, C. (2005). Yeni insan ve insanlar [New human and people]. Istanbul: Evrim Matbaacilik.

Kara, T. (2011). Gorsel medyanin aile bireyleri uzerindeki etkisi uzerine bir arastirma [A research on the effects of visual media on family members]. Retrieved from http://kutuphane.tuik.gov.tr/pdf/0021098.pdf

Karatekin. K., Merey. Z., \& Kus, Z. (2013). Ogretmen adaylari ve ogretmenlerin demokratik tutumlarinin cesitli degiskenler acisindan incelenmesi [Analysis of the democratic attitudes of pre-service teachers and teachers in terms of some variables]. Kastamonu Egitim Dergisi, 21(2) 561-574.

Kaya, C. (2013). Sinif ogretmenlerinin sinif yonetimindeki demokratik tutumlarinin incelenmesi. [Examining of democratic attitudes of class teachers in classroom management] (Unpublished master thesis). Ataturk Universitesi, Erzurum.

Kesici, A., Pesen, A., \& Oral, B. (2017). Examining teachers' democratic behaviors in the classroom according to various variables. Electronic Journal of Social Sciences, 16(60), 34-45.

Kincal, R. Y., \& Isik, H. (2003). Demokratik egitim ve demokratik degerler [Democratic education and democratic values]. Egitim Arastirmalari Dergisi, 3(11), 54-58.

Kirk, D. (1992). Physical education, discourse and ideology: Bringing the hidden curriculum into view. Quest, 44(1), 3456.

Kocoska, J. (2009). The student's position in the democratic classroom. Procedia Social and Behavioral Sciences, 1(2009) 2429-2431.

Kongar, E. (2007). Demokrasi ve kultur [Democracy and culture]. Istanbul: Remzi Kitapevi.

Kurnaz, A. (2011). Ilkogretim ogretmenlerinin yaraticilik duzeyleri ve demokratik tutumlari arasindaki iliskinin degerlendirilmesi [The evaluation of the relationship between the creativity levels of the primary school teachers and their democratic attitudes]. (Unpublished master thesis). Kahramanmaras Sutcu Imam Universitesi, Kahramanmaras.

Kucukahmet, L. (2009). Sinif yonetimi [Classroom management]. Ankara: Pegem Akademi Yayincilik.

Lakoff, G., \& Johnson, M. (2005). Metaforlar, hayat, anlam ve dil [Metaphors we live by]. (Translation. G. Y. Demir). Istanbul: Paradigma Yayinlari.

Miles, M. B., \& Huberman, A. M. (1994). Qualitative data analysis. London: Sage.

Ozcelik, I. (1995). Gorme ozurlu cocuklarin anne-baba tutumlari [Parental attitudes of visually handicapped children]. Yasadikca Egitim Dergisi, 41, 1-85.

Patton, M. Q. (2002). Qualitative research evulation methods. California: Sage.

Payne, K. A. (2017). Democratic teacher education in elementary classrooms - Learning about, through, and for thick democracy. The Journal of Social Studies Research, 41(2), 101-115.

Pehlivan, H. (1997). Tutumlarin dogasi ve ogretimi [Attitude teaching and the nature of the attitudes]. Cagdas Egitim Dergisi, 22(33) 46-48.

Peker, R. (2012). Sinif ogretmenlerinin demokratik tutumlari ile cocuk haklarina yonelik tutumlarinin degerlendirilmesi (Manisa ili ornegi) [The assessment of the class teachers democratic attitudes and attitudes regarding children's rights (Case Manisa)]. (Unpublished master thesis). Mehmet Akif Ersoy Universitesi, Manisa.

Print, M. (2007). Citizenship education and youth participation in democracy. British Journal of Educational Studies, 55(3), 325-345.

Rainer, J., \& Guyton, E. (1999). Democratic practices in teacher education and the elementary classroom. Teaching and Teacher Education, 15(1999) 121-132.

Richardson, V. (1993). The role of attitudes and beliefs in learning to teach. In J. Sikula (Ed.). Handbook of research on teacher education (p. 102-119). New York: Macmillan. 
Sadik, F., \& Sari, M. (2011). Ogretmen adaylari ve demokrasi: Sinif ogretmeni adaylarinin demokrasi algilarinin metaforlar yoluyla degerlendirilmesi [Teacher candidates and democracy: Evaluation of Teacher candidates' democracy perception by metaphors]. 10. Ulusal Sinif Ogretmenligi Egitimi Sempozyumu Bildiriler Kitabi, 1, 296303.

Samanci, O. (2010). Democracy education in elementary schools. The Social Studies, 101, 30-33.

Sari, M., \& Sadik, F. (2011). Democracy perception of teacher candidates: Cukurova University example. International Journal of Curriculum and Instructional Studies, 1(2), 67-82.

Sari, M. (2007). Demokratik degerlerin kazananimi surecinde ortuk program: dusuk ve yuksek okul yasam kalitesine sahip iki ilkogretim okulunda nitel bir calisma [The effect of hidden curriculum on gaining democratic values: a qualitative study in two elementary schools having low and high quality of school life]. (Unpublished doctoral thesis). Cukurova Universitesi, Adana.

Shechtman, Z. (2002). Validation of the democratic teacher belief scale (DTBS). Assessment in Education: Principles, Policy \& Practice, 9, 363-377.

Subba, D. (2014). Democratic values and democratic approach in teaching: A perspective. American Journal of Educational Research, 2(12A), 37-40.

Tuncel, I. (2008). Duyussal ozelliklerin gelisimi acisindan fiziki ortamdan kaynaklanan ortuk programin incelenmesi [Investigating hidden curriculum that emerges from the physical setting regarding affective characteristic development]. Balikesir Universitesi Sosyal Bilimler Enstitusu Dergisi, 11(20) 26-38.

Ustun, G. (2011). Sinif ogretmenlerinin yansitici dusunme egilimleri ile demokratik tutumlari arasindaki iliskinin incelenmesi [Investigate the relationship between the reflective thinking tendency and democratic attitude of class teachers]. (Unpublished master thesis). Marmara Universitesi, Istanbul.

Yalcin, B. (2014). Ogretmenlerin demokratik tutumlarinin ogrencilerin deger kazanimlarina etkisi: Erzurum ili ornegi [The effect of teachers' democratic attitudes on students' acquisition of values: Example of the city of Erzurum]. (Unpublished master thesis). Ataturk Universitesi, Erzurum.

Yildirim, A., \& Simsek, A. (2011). Sosyal bilimlerde nitel arastirma yontemleri [Qualitative research methods for the social sciences]. Ankara: Seckin Yayinevi.

Yuksel, S. (2004). Ortuk program: Egitimde sakli uygulamalar [Hidden curriculum: Hidden applications in education]. Ankara: Nobel Yayinevi. 